\title{
Synthesis, Characterization and Antibacterial Evaluation of Some New Nickel(II) Complexes of a Tetraazamacrocycle
}

\section{Pradip Paul $^{1}$, Saswata Rabi ${ }^{1,2}$, Proma Kanungoe ${ }^{1}$, Sidratul Muntaha ${ }^{1}$, Debashis Palit ${ }^{1}$ and Tapashi Ghosh Roy ${ }^{1 *}$ \\ ${ }^{1}$ Department of Chemistry, University of Chittagong, Chattogram, Bangladesh \\ 2Department of Chemistry, Chittagong University of Engineering and Technology, Chattogram, Bangladesh}

*Corresponding Author: Tapashi Ghosh Roy, Department of Chemistry, University of Chittagong, Bangladesh.
Received: November 20, 2020

Published: December 22, 2020

(C) All rights are reserved by Tapashi Ghosh

Roy., et al.

\begin{abstract}
Condensation of 1,2-diaminopropane with acetone in the presence of quantitative amount of perchloric acid, yielded a 14-membered octamethyl tetraazamacrocyclic dihydroperchlorate salt, $\mathrm{Me}_{8}[14]$ diene. $2 \mathrm{HClO}_{4}\left(\mathrm{~L} .2 \mathrm{HClO}_{4}\right)$, which on extraction with chloroform at $\mathrm{pH}$ above 12 produced free ligand, $\mathrm{L}$. The reaction between nickel(II) nitrate hexahydrate and the free ligand $\mathrm{L}$ resulted in a five coordinated square pyramidal light violet complex $\left[\mathrm{NiL}\left(\mathrm{NO}_{3}\right)\right]\left(\mathrm{NO}_{3}\right)$. Moreover some substituted nickel(II) salts, $\mathrm{Ni}(\mathrm{NCS})_{2}, \mathrm{NiCl}{ }_{2}$, $\mathrm{NiBr}_{2}, \mathrm{NI}_{2}$ and $\mathrm{Ni}\left(\mathrm{NO}_{2}\right)_{2}$ prepared in solution (with a possibility of existence of negligible amount of $\mathrm{NO}_{3}^{-}$ion) by the interaction of nickel(II) nitrate hexahydrate with $\mathrm{KX}\left(\mathrm{X}=\mathrm{SCN}, \mathrm{Cl}, \mathrm{Br}\right.$ or I) and $\mathrm{NaNO}_{2}$ respectively on reactions with the concerned ligand $\mathrm{L}$ furnished orange yellow [NiL](SCN) $)_{2}$ and light pink [NiL(NCS)](SCN), light purple [NiLCl]Cl, brownish $[\mathrm{NiL}] \mathrm{Br}_{2}$ and light purple $[\mathrm{NiLBr}] \mathrm{Br}$, light purple [NiLI]I and light pink $\left[\mathrm{NiL}\left(\mathrm{NO}_{2}\right)\right]\left(\mathrm{NO}_{3}\right)$ respectively. Among them, [NiL(NCS)](SCN), [NiLCl]Cl, [NiLBr]Br, [NiLI]I and $\left[\mathrm{NiL}\left(\mathrm{NO}_{2}\right)\right]\left(\mathrm{NO}_{3}\right)$ were analysed as five coordinated square pyramidal and [NiL] $(\mathrm{SCN})_{2}$ and $[\mathrm{NiL}] \mathrm{Br}{ }_{2}$ as four coordinated square planar in geometry. All these complexes have been characterized on the basis of analytical, spectroscopic, conductometric and magnetochemical data. The antimicrobial activities of the ligand and its new nickel(II) complexes have been evaluated against some selected gram positive and gram negative bacteria.
\end{abstract}

Keywords: Tetraazamacrocyclic Ligand; Nickel(II) Complexes; Spectral Analysis; Antibacterial Evaluation

\section{Introduction}

The structural, thermodynamic and kinetic studies of polyazamacrocyclic ligands and their complexes have drawn a great attention due to their significant implication in analytical, biological and other applications [1-10] in the field of coordination chemistry. However, there is a similarity in structure and biomedical applications of these complexes with some natural macrocycles such as erythromycin A, vancomycin, amphotericin B etc. which are important in the area of medicinal chemistry [2]. The interest of exploring the macrocyclic structures and macrocyclization reaction is due to their biological activities including antiviral, anticarcinogenic [3], antifertility [4], antibacterial and antifungal [5] activities. The biological analysis of these compounds also give a strong evidence about their anticancer [6], antitumor [7] anti-inflammatory
[8] antioxidant [9] and anti-HIV activities [10]. Metal like nickel, copper, cobalt and manganese have high ability for coordination because of their smaller size and higher nuclear charge [11].

An exhaustive number of nickel(II) complexes with different macrocycles are available in literature [12-19]. In our previous study, metal complexes of 3,10-C-meso- $\mathrm{Me}_{8}[14]$ diene (L) (Scheme 1) and it's reduced isomeric anes $\left(L_{A}, L_{B}\right.$ and $\left.L_{C}\right)$ [20-23] and few $\mathrm{N}$-pendent derivative ligands of the isomeric ligands, $\mathrm{Me}_{8}[14]$ anes [i.e. $\mathrm{L}_{\mathrm{B}}$ and $\mathrm{L}_{\mathrm{C}}$ ] and their metal complexes have been reported [2425]. Moreover one study [23] on analogous zinc(II) complexes reveals that the square pyramidal zinc(II) complex can undergo subsequent axial addition and axial substitution reactions. As per previous reports [26,27], our group was successful in preparing 
an octahedral diperchloretocopper(II) complex, $\left[\mathrm{CuL}\left(\mathrm{ClO}_{4}\right)_{2}\right]$ of $\mathrm{Me}_{8}[14]$ diene and its axial substitution products and the structure of mother complex, $\left[\mathrm{CuL}\left(\mathrm{ClO}_{4}\right)_{2}\right]$ was confirmed by X-ray crystallography [27]. So it was interesting to see whether four or five coordinated complexes of free $\mathrm{Me}_{8}[14]$ diene ligand (L) could be prepared using nickel(II) salt or substituted nickel(II) salt. Thus an effort to prepare some new nickel(II) complexes of free ligand $\mathrm{L}$ [26] was successful. This study reveals that the concerned free ligand L undergoes complexation with nickel(II) nitrate hexahydrate to result a five-coordinated square pyramidal complex [NiL( $\left.\left.\mathrm{NO}_{3}\right)\right]$ $\left(\mathrm{NO}_{3}\right)$ with $\mathrm{sp}^{3} \mathrm{~d}$ hybridization. It is also noticed that attempts to produce some nickel(II) complexes of the ligand L with substituted nickel(II) salts (produced from nickel(II) nitrate hexahydrate) were successful. Thus interaction of the ligand L with metal salts like $\mathrm{Ni}(\mathrm{SCN})_{2}, \mathrm{NiCl}_{2}, \mathrm{NiBr}_{2}, \mathrm{NiI}_{2}$ and $\mathrm{Ni}\left(\mathrm{NO}_{2}\right)_{2}$ [produced by the reactions of $\mathrm{Ni}\left(\mathrm{NO}_{3}\right)_{2} \cdot 6 \mathrm{H}_{2} \mathrm{O}$ with $\mathrm{KX}\left(\mathrm{X}=\mathrm{SCN}, \mathrm{Cl}, \mathrm{Br}\right.$ or I) and $\mathrm{NaNO}_{2}$ respectively] resulted in square planar $[\mathrm{NiL}](\mathrm{SCN})_{2}$ and square pyramidal [NiL(NCS)](SCN), square pyramidal [NiLCl]Cl, square planar [NiL] $\mathrm{Br}_{2}$ and square pyramidal $[\mathrm{NiLBr}] \mathrm{Br}$, square pyramidal [NiLI]I and [NiL( $\left.\left.\mathrm{NO}_{2}\right)\right]\left(\mathrm{NO}_{3}\right)$ respectively. The free ligand $\mathrm{L}$ and its nickel(II) complexes have been characterized on the basis of analytical, spectroscopic, conductometric and magnetochemical data. The antibacterial activities of the ligand and its new nikel(II) complexes have been investigated against both gram positive and gram negative bacteria. Thus herein we report, the synthesis, characterization and antibacterial evaluation of the concerned ligand and its new nickel(II) complexes.

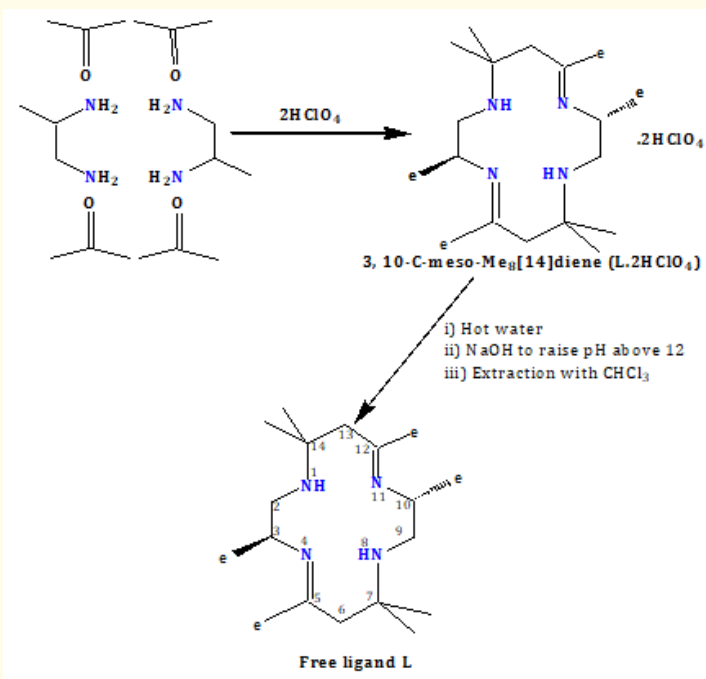

Scheme 1: Preparation of free ligand 3,10-C-meso-Me8[14]diene (L).

\section{Materials and Methods}

All chemicals were of analytical grade (Sigma Aldrich) or equivalent grades and were used without further purification. The solvents were of reagent grade and dried according to standard procedure. Equipment used were of standard ones. Microanalysis of $\mathrm{C}$, $\mathrm{H}$ and $\mathrm{N}$ of the complexes has been carried out on a $\mathrm{C}, \mathrm{H}, \mathrm{N}$ analyzer at the Department of Chemistry, Friedrich Schiller University, Jena, Germany. IR spectra were recorded on a Shimadzu IR 20 spectrophotometer as $\mathrm{KBr}$ disks. UV- visible spectra were recorded on a Shimadzu UV-visible spectrophotometer in DMSO, Acetonitrile and $\mathrm{H}_{2} \mathrm{O}$. Conductance measurements were carried out on a conductivity bridge Hanna instrument HI-8820 in pure DMSO, Acetonitrile and $\mathrm{H}_{2} \mathrm{O}$. Magnetic measurements were performed on Gouy Balance which was calibrated using $\mathrm{Hg}\left[\mathrm{Co}(\mathrm{NCS})_{4}\right] .{ }^{1} \mathrm{H}-\mathrm{NMR}$ spectra were recorded in DMSO with a $400 \mathrm{MHz}$ Bruker DPX-400 spectrometer using TMS as internal standard at the BCSIR Laboratory, Dhaka, Bangladesh.

\section{Syntheses}

\section{Free ligand, L}

Synthesis of free ligand $\mathrm{Me}_{8}[14]$ diene. $2 \mathrm{HClO}_{4}$ (L) (Scheme-1) was carried out as procedure adopted in our earlier studies [26].

\section{Nickel(II) complexes of free ligand L}

Preparation of nickel(II) complex $\left[\mathrm{NiL}\left(\mathrm{NO}_{3}\right)\right]\left(\mathrm{NO}_{3}\right)$ by the direct reaction of L with nickel(II) nitrate hexahydrate

$0.291 \mathrm{~g}(1.0 \mathrm{mmol})$ nickel(II) nitrate hexahydrate was dissolved in $30 \mathrm{~mL}$ of methanol and the solution was heated untill concentrated to $5 \mathrm{~mL}$ and cooled. The precipitate was filtered off. $30 \mathrm{~mL}$ methanolic solution of $0.308 \mathrm{~g}(1.0 \mathrm{mmol}) \mathrm{L}$ was added to the filtrate in a round bottom flask. The solution was refluxed for 4 hours. On evaporation of the solvent, solid material was obtained which was extracted with chloroform living behind an insoluble solid. On evaporation of the chloroform extract a small amount of greenish product was obtained which was very negligible in amount to be characterized. However the insoluble part in chloroform was treated with ethanol and the ethanolic solution was dried. The light violet product was resulted which was stored in a vacuum desiccator.

[NiL( $\left.\left(\mathrm{NO}_{3}\right)\right]\left(\mathrm{NO}_{3}\right) \quad\left(\mathrm{C}_{18} \mathrm{H}_{36} \mathrm{~N}_{6} \mathrm{O}_{6} \mathrm{Ni}\right)$ : Color: Light violet. Decomposition point: $194^{\circ} \mathrm{C}$. Anal. Calcd. (\%): C, 44.01; H, 7.39; N, 17.10. Found (\%): C, 44.07; H, 7.35; N, 17.07. IR (KBr disc, $\mathrm{cm}^{-1}$ ): $v_{\mathrm{N}-\mathrm{H}^{\prime}}, 3190 \mathrm{w} ; v_{\mathrm{C}-\mathrm{H}^{\prime}}, 2964 \mathrm{~s} ; v_{\mathrm{CH} 3}, 1383 \mathrm{~s} ; v_{\mathrm{C}-\mathrm{C}}, 1150 \mathrm{~s} ; v_{\mathrm{N}-\mathrm{Ni}}, 538 \mathrm{w} ; v_{\mathrm{N} 03^{\prime}}$ $831 \mathrm{~s}\left(\mathrm{v}_{2}\right), 1383 \mathrm{vs}\left(\mathrm{v}_{3}\right), 668 \mathrm{~s}\left(\mathrm{v}_{4}\right), 1325 \mathrm{w}, 1440 \mathrm{w}$. Conductance $\left(\mathrm{ohm}^{-}\right.$

Citation: Tapashi Ghosh Roy., et al. "Synthesis, Characterization and Antibacterial Evaluation of Some New Nickel(II) Complexes of a Tetraazamacrocycle". Acta Scientific Pharmaceutical Sciences 5.1 (2020): 60-69. 
${ }^{1} \mathrm{~cm}^{2} \mathrm{~mol}^{-1}$ ): in DMSO 114; in Acetonitrile 250; in $\mathrm{H}_{2} \mathrm{O} 217$. UV-vis [ $\lambda$ max in $\mathrm{nm}\left(\varepsilon_{\text {max }}\right.$ in $\left.\mathrm{M}^{-1} \mathrm{~cm}^{-1}\right)$ ]: in DMSO 795(15), 570(32), 356(25), 285(4000); in Acetonitrile 790(17), 555(13), 342(30), 275(2801); in $\mathrm{H}_{2} \mathrm{O} 796(28), 566(11), 465(92), 356(24), 280(3800)$. Magnetic moment $\mu_{\text {eff }}(\mathrm{BM}): 3.006$.

Preparation of nickel(II) complexes by the reactions of $L$ with substituted nickel(II) salts

\section{$[\mathrm{NiL}](\mathrm{SCN})_{2}$ and $[\mathrm{NiL}(\mathrm{NCS})](\mathrm{SCN})$}

$0.291 \mathrm{~g}$ (1.0 mmol) of nickel(II) nitrate hexahydrate and 0.194 $\mathrm{g}(2.0 \mathrm{mmol})$ of potassium thiocyanate were dissolved in $30 \mathrm{~mL}$ of methanol and the solution was heated untill concentrated to $5 \mathrm{~mL}$ and cooled. The precipitate was filtered off. $30 \mathrm{~mL}$ methanolic solution of $0.308 \mathrm{~g}(1.0 \mathrm{mmol}) \mathrm{L}$ was added to the filtrate in a round bottom flask. The solution was refluxed for $2 \mathrm{~h}$. On evaporation of the solvent, solid material was obtained which was extracted with chloroform living behind an insoluble solid. On evaporation of the chloroform extract, yellow product of $[\mathrm{NiL}](\mathrm{SCN})_{2}$ was obtained which was no more soluble in chloroform. On the other hand the insoluble part in chloroform was treated with ethanol and the etahnolic solution was dried. The light pink product of [NiL(NCS)] (SCN) was resulted which was stored in vacuum desiccator.

[NiL](SCN) $)_{2}\left(\mathrm{C}_{20} \mathrm{H}_{36} \mathrm{~N}_{6} \mathrm{~S}_{2} \mathrm{Ni}\right)$ : Color: Yellow. Decomposition point: $190^{\circ} \mathrm{C}$. Anal. Calcd. (\%): C, 49.69; H, 7.51; N, 17.39. Found (\%): C, 49.65; H, 7.57; N, 17.34. IR ( $\mathrm{KBr}$ disc, $\left.\mathrm{cm}^{-1}\right): \mathrm{v}_{\mathrm{N}-\mathrm{H}} 3064 \mathrm{~s} ; \mathrm{v}_{\mathrm{C}-\mathrm{H},} 2970 \mathrm{~s}$; $v_{\mathrm{CH} 3}, 1383 \mathrm{~s} ; v_{\mathrm{C}-\mathrm{C},} 1145 \mathrm{~s} ; v_{\mathrm{N}-\mathrm{Ni}}$ 585s; $v_{\mathrm{NCS}}, 2035 \mathrm{vs} .{ }^{1} \mathrm{H}$ NMR $(\delta, \mathrm{ppm})$ : Geminal dimethyl and Methyl proton on chiral carbon, 0.884 (ov, $12 \mathrm{H}, \mathrm{e}), 1.282(\mathrm{~s}, 6 \mathrm{H}, \mathrm{a})$; Methyl protons on $\mathrm{sp}^{2}$ carbons, 1.602 (s, $6 \mathrm{H}, \mathrm{e}) ; \mathrm{CH}_{2}$ and $\mathrm{CH}$ protons, 2.000, 2.250, 2.600, 4.000, 4.900; $\mathrm{NH}$ proton, 7.220. Conductance $\left(\mathrm{ohm}^{-1} \mathrm{~cm}^{2} \mathrm{~mol}^{-1}\right)$ : in DMSO 95; in Acetonitrile 214; in $\mathrm{H}_{2} \mathrm{O}, 191$. UV-vis [ $\lambda_{\text {max }}$ in $\mathrm{nm}\left(\varepsilon_{\text {max }}\right.$ in $\left.\mathrm{M}^{-1} \mathrm{~cm}^{-1}\right)$ ]: in DMSO 435(109), 565(64), 615(81); in Acetonitrile 445(74); in $\mathrm{H}_{2} \mathrm{O}, 436(81) ; 436(81), 340(76), 287(3966)$. Magnetic moment $\mu_{\text {eff }}$ (BM): Diamagnetic.

[NiL(NCS)](SCN) $\left(\mathrm{C}_{20} \mathrm{H}_{36} \mathrm{~N}_{6} \mathrm{~S}_{2} \mathrm{Ni}\right)$ : Color: Light pink. Melting point: $188^{\circ} \mathrm{C}$. Anal. Calcd. (\%): C, 49.69; H, 7.51; N, 17.39. Found (\%): C, 49.62; H, 7.59; N, 17.31. IR (KBr disc, $\left.\mathrm{cm}^{-1}\right): v_{\mathrm{N}-\mathrm{H}}, 3152 \mathrm{w} ; \mathrm{v}_{\mathrm{C}-}$ ${ }_{\mathrm{H}}, 2961 \mathrm{~s} ; \mathrm{v}_{\mathrm{CH} 3}, 1383 \mathrm{vs} ; \mathrm{v}_{\mathrm{C}-\mathrm{C}}, 1150 \mathrm{~s} ; \mathrm{v}_{\mathrm{N}-\mathrm{Ni}}, 538 \mathrm{~s} ; \mathrm{v}_{\mathrm{NCS}}, 2051 \mathrm{vs} ; \mathrm{v}_{\mathrm{CS}}, 835 \mathrm{~s}$; $\boldsymbol{\delta}_{\mathrm{NCS}}, 482 \mathrm{~s}$. Conductance, $\left(\mathrm{ohm}^{-1} \mathrm{~cm}^{2} \mathrm{~mol}^{-1}\right)$ : in DMSO 104; in $\mathrm{H}_{2} \mathrm{O}$, 241. UV-vis [ $\lambda_{\text {max }}$ in nm $\left(\varepsilon_{\text {max }}\right.$ in $\left.\mathrm{M}^{-1} \mathrm{~cm}^{-1}\right)$ ]: in DMSO 798(15), 545(27), 340(25); in $\mathrm{H}_{2} \mathrm{O}$ 796(11), 550(15), 468(95), 340(35). Magnetic moment $\mu_{\mathrm{eff}}$ (B.M): 3.006.
$\left[\mathrm{NiL}\left(\mathrm{NO}_{2}\right)\right]\left(\mathrm{NO}_{3}\right)$

The complex was prepared by following the above mentioned procedure adopted for preparation nickel(II) thiocyante complexes by adding sodium nitrite instead of KSCN. But in this preparation, a small amount of chloroform soluble brownish product was obtained which was very negligible in amount to be characterized. However the other insoluble part in chloroform was treated with ethanol and the etahnolic solution was dried. The light pink product was resulted which was stored in a vacuum desiccator.

[NiL( $\left.\left(\mathrm{NO}_{2}\right)\right]\left(\mathrm{NO}_{3}\right)\left(\mathrm{C}_{18} \mathrm{H}_{36} \mathrm{~N}_{6} \mathrm{O}_{5} \mathrm{Ni}\right)$ : Color: Light pink. Decomposition point: $188-190^{\circ} \mathrm{C}$. Melting point: $204^{\circ} \mathrm{C}$, Anal. Calcd. (\%): C, 45.49; H, 7.64; N, 11.79. Found (\%): C, 45.51; H, 7.62; N, 11.74. IR $\left(\mathrm{KBr}\right.$ disc, $\left.\mathrm{cm}^{-1}\right): v_{\mathrm{N}-\mathrm{H}^{\prime}}, 3166 \mathrm{w} ; \mathrm{v}_{\mathrm{C}-\mathrm{H}}, 2962 \mathrm{~m} ; v_{\mathrm{CH} 3}, 1383 \mathrm{~s} ; \mathrm{v}_{\mathrm{C}-\mathrm{C}}, 1157 \mathrm{~s}$; $v_{\mathrm{N}-\mathrm{Ni}}, 543 \mathrm{w} ; v_{\text {asym(NO2) }}, 1459 \mathrm{w} ; v_{\text {sym(NO2) }}, 1320 \mathrm{w}, \delta_{\mathrm{NO} 2} 650 \mathrm{w}, v_{\mathrm{NO} 3}, 1383 \mathrm{~s}$. Conductance $\left(\mathrm{ohm}^{-1} \mathrm{~cm}^{2} \mathrm{~mol}^{-1}\right)$ : in DMSO 96; in $\mathrm{H}_{2} \mathrm{O} 231$. UV-vis [ $\lambda$ max in $\mathrm{nm}\left(\varepsilon_{\max }\right.$ in $\left.\mathrm{M}^{-1} \mathrm{~cm}^{-1}\right)$ ]: in DMSO 798(22), 543(35), 371(54); in $\mathrm{H}_{2} \mathrm{O}$ 794(4), 553(6), 356(43). Magnetic moment $\mu_{\text {eff }}$ (B.M): 3.035.

$\left[\mathrm{NiLX}_{\mathrm{m}}\right] \mathrm{X}_{\mathrm{n}}(\mathrm{X}=\mathrm{Cl}, \mathrm{Br}$ or $\mathrm{I}, \mathrm{m}=0$ or 1 and $\mathrm{n}=2$ or 1$)$

These complexes were also prepared by the procedure adopted for nickel(II) thiocyante complexes by adding $\mathrm{KX}$ in the proper ratio. On evaporation of the solvent, solid material was obtained which was extracted with chloroform living behind an insoluble solid. On evaporation of the chloroform extract a small amount of brownish product was obtained which was very negligible in amount for chloride and iodide complex to be characterized but it was sufficient for bromide complex. However the extracted brownish $[\mathrm{NiL}] \mathrm{Br}_{2}$ product with $\mathrm{CHCl}_{3}$ was no more soluble in $\mathrm{CHCl}_{3}$. On the other hand the insoluble part in chloroform was treated with ethanol and the ethanolic solution on drying resulted in the light purple product in all cases which were stored in a vacuum desiccator.

[NiLCl]Cl $\left(\mathrm{C}_{18} \mathrm{H}_{36} \mathrm{~N}_{4} \mathrm{Cl}_{2} \mathrm{Ni}\right)$ : Color: Light purple. Decomposition point: $190^{\circ} \mathrm{C}$. Anal. Calcd. (\%): C, 49.35; H, 8.28; N, 12.79. Found (\%): C, 49.29; H, 8.31; N, 12.71. IR ( $\mathrm{KBr}$ disc, $\mathrm{cm}^{-1}$ ): $\mathrm{v}_{\mathrm{N}-\mathrm{H}} 3167 \mathrm{w}$; $v_{\mathrm{C}-\mathrm{H},} 2962 \mathrm{w} ; v_{\mathrm{CH} 3}, 1383 \mathrm{~s} ; v_{\mathrm{C}-\mathrm{C},} 1158 \mathrm{~s} ; v_{\mathrm{N}-\mathrm{Ni},} 536 \mathrm{w}$. Conductance $\left(\mathrm{ohm}^{-}\right.$ ${ }^{1} \mathrm{~cm}^{2} \mathrm{~mol}^{-1}$ ): in DMSO, 73 ; in $\mathrm{H}_{2} \mathrm{O}, 256$. UV vis $\left[\lambda_{\max }\right.$ in $\mathrm{nm}(\varepsilon$ max ]: in DMSO 797(5), 536(7), 348(11); in $\mathrm{H}_{2} \mathrm{O}$ 794(9), 551(12), 485(102), 340(25). Magnetic moment $\mu_{\text {eff }}(\mathrm{BM}): 3.073$.

[NiL]Br ${ }_{2}\left(\mathrm{C}_{18} \mathrm{H}_{36} \mathrm{~N}_{4} \mathrm{Br}_{2} \mathrm{Ni}\right):$ Color: Brownish. Decomposition point: $195^{\circ} \mathrm{C}$. Anal. Calcd. (\%): C, 41.02; H, 6.89; N, 10.63. Found 
(\%): C, 41.08; H, 6.83; N, 10.69. IR (KBr disc, $\left.\mathrm{cm}^{-1}\right): v_{\mathrm{N}-\mathrm{H},} 3140 \mathrm{w}$; $v_{\mathrm{C}-\mathrm{H}} 2950 \mathrm{w} ; v_{\mathrm{CH} 3}, 1383 \mathrm{~s} ; v_{\mathrm{C}-\mathrm{C},} 1155 \mathrm{~s} ; v_{\mathrm{N}-\mathrm{Ni}}, 530 \mathrm{w}$. Conductance $\left(\mathrm{ohm}^{-}\right.$ $\left.{ }^{1} \mathrm{~cm}^{2} \mathrm{~mol}^{-1}\right)$ : in DMSO 75; in $\mathrm{H}_{2} \mathrm{O} 208$. UV vis $\left[\lambda_{\max }\right.$ in $\left.\mathrm{nm}\left(\varepsilon_{\max }\right)\right]$ : in DMSO 448(44); in $\mathrm{H}_{2} \mathrm{O}$ 443(47). Magnetic moment $\mu_{\text {eff }}(\mathrm{BM})$ : Diamagnetic. ${ }^{1} \mathrm{H}$ NMR $(\delta$, ppm): Geminal dimethyl and Methyl proton on chiral carbon, $1.26(\mathrm{~s}, 6 \mathrm{H}, \mathrm{e}), 1.36(\mathrm{~s}, 6 \mathrm{H}, \mathrm{a}), 1.05(\mathrm{~d}, 6 \mathrm{H}, \mathrm{e})$; Methyl protons on $\mathrm{sp}^{2}$ carbons, $2.09(\mathrm{~s}, 6 \mathrm{H}, \mathrm{e}) ; \mathrm{CH}_{2}, \mathrm{CH}$ and $\mathrm{NH}$ protons, $1.90(\mathrm{~s}, 4 \mathrm{H}), 2.75(\mathrm{~m}), 3.20(\mathrm{~m})$.

[NiLBr]Br $\left(\mathrm{C}_{18} \mathrm{H}_{36} \mathrm{~N}_{4} \mathrm{Br}{ }_{2} \mathrm{Ni}\right)$ : Color: Light purple. Melting point: 197-201\% C. Anal. Calcd. (\%): C, 41.02; H, 6.89; N, 10.63. Found (\%): C, 41.06; H, 6.87; N, 10.58. IR (KBr disc, $\left.\mathrm{cm}^{-1}\right): v_{\mathrm{N}-\mathrm{H}^{\prime}}, 3159 \mathrm{w} ; \mathrm{v}_{\mathrm{C}-\mathrm{H}^{\prime}}$ $2961 \mathrm{w} ; v_{\mathrm{CH} 3}, 1383 v s ; v_{\mathrm{C}-\mathrm{C}^{\prime}}, 1156 \mathrm{~s} ; v_{\mathrm{N}-\mathrm{Ni}^{\prime}}, 534 \mathrm{w}$. Conductance (ohm $\left.{ }^{1} \mathrm{~cm}^{2} \mathrm{~mol}^{-1}\right)$ : in DMSO, 90; in $\mathrm{H}_{2} \mathrm{O}, 250$. UV vis [ $\lambda_{\text {max }}$ in $\left.\mathrm{nm}\left(\varepsilon_{\text {max }}\right)\right]$ : in DMSO, 585(54), 675(81), 797(27), 541(18), 348(67); in $\mathrm{H}_{2} \mathrm{O}$ 798(17), 550(29), 468(92), 348(77). Magnetic moment $\mu_{\text {eff }}(B M)$ : 3.09 .

[NiLI]I $\left(\mathrm{C}_{18} \mathrm{H}_{36} \mathrm{~N}_{4} \mathrm{I}_{2} \mathrm{Ni}\right)$ : Color: Light purple. Decomposition point: $224^{\circ}$ C. Anal. Calcd. (\%): C, 34.81; H, 5.84; N, 9.02. Found (\%): C, 34.75; H, 5.81; N, 9.08. IR ( $\mathrm{KBr}$ disc, $\mathrm{cm}^{-1}$ ): $v_{\mathrm{N}-\mathrm{H}} 3138 \mathrm{w} ; v_{\mathrm{C}-\mathrm{H},} 2961 \mathrm{~s}$; $v_{\mathrm{CH} 3}, 1383 \mathrm{~s} ; v_{\mathrm{C}-\mathrm{C}}, 1149 \mathrm{~s} ; v_{\mathrm{N}-\mathrm{Ni}}, 534 \mathrm{~s}$. Conductance $\left(\mathrm{ohm}^{-1} \mathrm{~cm}^{2} \mathrm{~mol}^{-1}\right)$ : in DMSO, 92; in $\mathrm{H}_{2} \mathrm{O} 214$; UV-vis [ $\lambda_{\max }$ in $\mathrm{nm}\left(\varepsilon_{\max }\right.$ in $\left.\left.\mathrm{M}^{-1} \mathrm{~cm}^{-1}\right)\right]$ : in DMSO 795(37), 543(13), 340(78); in $\mathrm{H}_{2} \mathrm{O}$ 798(12), 548(15), 475(97), 346(28). Magnetic moment $\mu_{\text {eff }}$ (B.M): 3.023.

\section{Antibacterial activities}

Antibacterial activities of the ligand and its nickel(II) complexes were performed by the disc diffusion method against selected gram-positive and gram-negative bacteria. Solutions of known concentration $(0.1 \%)$ of the test samples were made by dissolving the samples in definite volume of solvents. Dried and sterilized filter paper discs ( $4 \mathrm{~mm}$ in diameter) are then impregnated with known amount of test substances using micropipette and these were then allowed to dry. Discs containing the test material were placed on nutrient agar medium uniformly seeded with the test microorganism. A control plate was also maintained in each case with DMSO. These plates were then kept at low temperature $\left(4^{\circ} \mathrm{C}\right)$ for $2-4 \mathrm{~h}$ to allow maximum diffusion. During this time dried discs absorbed water from the surrounding media and then the test materials were dissolved and diffused out of the media. The plates were then incubated at $(35 \pm 2)^{\circ} \mathrm{C}$ for the growth of test organisms and were observed at 48 hours intervals. The activity was expressed in terms of zone of inhibition in $\mathrm{mm}$. The activities of non-coordinated metal salt $\mathrm{Ni}\left(\mathrm{NO}_{3}\right)_{2} \cdot 6 \mathrm{H}_{2} \mathrm{O}$, a commercial standard (Ampiciline) were also tested against all bacteria accordingly for the comparison. Tests were repeated thrice for statistical analysis.

\section{Results and Discussion}

Ligands

The free ligand L was prepared (Scheme 1) and characterized by the procedure adopted in our previous study [26].

\section{Characterization}

\section{$\left[\mathrm{NiL}\left(\mathrm{NO}_{3}\right)\right]\left(\mathrm{NO}_{3}\right)$}

Interaction between the nickel(II) nitrate hexahydrate and free ligand L in methanol produced five coordinated square pyramidal light violet product, $\left[\mathrm{NiL}\left(\mathrm{NO}_{3}\right)\right]\left(\mathrm{NO}_{3}\right)$. The infrared spectrum of this complex (Table-2) displays $\mathrm{v}_{\mathrm{N}-\mathrm{H}}, \mathrm{v}_{\mathrm{C}-\mathrm{C},}, \mathrm{v}_{\mathrm{C}-\mathrm{H},}, \mathrm{v}_{\mathrm{Ni}-\mathrm{N}}$ and $\mathrm{v}_{\mathrm{CH} 3}$ bands at 3190 $\mathrm{cm}^{-1}, 1150 \mathrm{~cm}^{-1}, 2964 \mathrm{~cm}^{-1}, 538 \mathrm{~cm}^{-1}$ and $1383 \mathrm{~cm}^{-1}$ respectively. The complex $\left[\mathrm{NiL}\left(\mathrm{NO}_{3}\right)\right]\left(\mathrm{NO}_{3}\right)$ exhibits bands at three frequencies assigned to vibrational modes $v_{2}=831 \mathrm{~cm}^{-1}, v_{3}=1383 \mathrm{~cm}^{-1}$ and $v_{4}=668 \mathrm{~cm}^{-1}$ for $v_{\mathrm{NO3}}$ [26]. Moreover this complex displays bands at $1325 \mathrm{~cm}^{-1}$ and $1440 \mathrm{~cm}^{-1}$ showing separation of bands by $115 \mathrm{~cm}^{-1}$ indicating unidentate mode of coordination [28]. Further appearance of a band at $1383 \mathrm{~cm}^{-1}$ is due to ionic $\mathrm{NO}_{3}^{-}$group overlapped with the band for $v_{\mathrm{CH} 3}$. The complex $\left[\mathrm{NiL}\left(\mathrm{NO}_{3}\right)\right]\left(\mathrm{NO}_{3}\right)$ reveals molar conductivity value $114 \mathrm{ohm}^{-1} \mathrm{~cm}^{2} \mathrm{~mol}^{-1}$ in DMSO (in this solvent it retains its color intact) corresponding to $1: 1$ electrolyte as expected for formula assigned. However the molar conductivity values of 250 and $217 \mathrm{ohm}^{-1} \mathrm{~cm}^{2} \mathrm{~mol}^{-1}$ of the complex in acetonitrile and $\mathrm{H}_{2} \mathrm{O}$ corresponding to 1:2 electrolyte [29] can be accounted for expulsion of an anion i.e. $\left(\mathrm{NO}_{3}^{-}\right)$from coordination sphere to form square planar complex $[\mathrm{NiL}]\left(\mathrm{NO}_{3}\right)_{2}$ as expressed by the expression-1 or for the conversion of square pyramidal to octahedral aqua complex in $\mathrm{H}_{2} \mathrm{O}$ as shown by the expression- 2 .

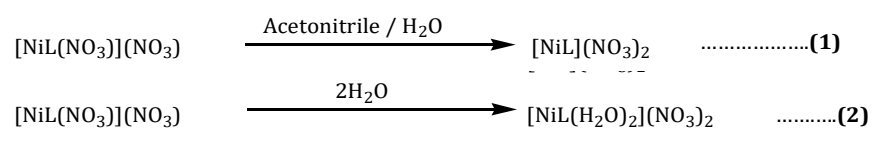

The magnetic moment value of $3.006 \mathrm{BM}$ of the complex $\left[\mathrm{NiL}\left(\mathrm{NO}_{3}\right)\right]\left(\mathrm{NO}_{3}\right)$ demonstrates that the complex is paramagnetic corresponding to two unpaired electrons as expected for square pyramidal complex with $\mathrm{sp}^{3} \mathrm{~d}$ hybridization [30]. Electronic spectrum of $\left[\mathrm{NiL}\left(\mathrm{NO}_{3}\right)\right]\left(\mathrm{NO}_{3}\right)$ reveals bands at $342-356 \mathrm{~nm}, 555-570$ $\mathrm{nm}, 790-796 \mathrm{~nm}$ in concerned solvents assignable to the ${ }^{3} \mathrm{~B}_{1 \mathrm{~g}} \rightarrow{ }^{3} \mathrm{E}_{\mathrm{g}}$ $\left[\mathrm{T}_{1 \mathrm{~g}}(\mathrm{P})\right],{ }^{1} \mathrm{~B}_{2 \mathrm{~g}} \rightarrow{ }^{1} \mathrm{~B}_{1 \mathrm{~g}}{ }^{3} \mathrm{~B}_{1 \mathrm{~g}} \rightarrow{ }^{3} \mathrm{~B}_{2 \mathrm{~g}}\left[\mathrm{~T}_{2 \mathrm{~g}}(\mathrm{~F})\right]$ transitions respectively, which are characteristic bands expected for a high-spin $\mathrm{d}^{8}$ nickel(II) ion 
[31]. This study supports the square pyramidal geometry of the complex $\left[\mathrm{NiL}\left(\mathrm{NO}_{3}\right)\right]\left(\mathrm{NO}_{3}\right)$ having $\mathrm{sp}^{3} \mathrm{~d}$ hybridization. But the value $456 \mathrm{~nm}$ in $\mathrm{H}_{2} \mathrm{O}$ supports the existence of square planar species too. However the bands at 275-285 $\mathrm{nm}$ for this complex can be accounted for charge transfer transitions. Since this is a paramagnetic complex and NMR spectra of paramagnetic complexes are less informative, so ${ }^{1} \mathrm{H}$-NMR spectrum of this complex has not been measured. However the stereochemistry (axial-equatorial orientation) of this complex has been assigned as corresponding square pyramidal zinc(II) complex [32] and square planar nickel(II) complexes of this study. The similar assignment has been made for other paramagnetic square pyramidal complexes of this study. Thus based on these evidences, the structure-I can be assigned for [NiL( $\left.\left.\mathrm{NO}_{3}\right)\right]$

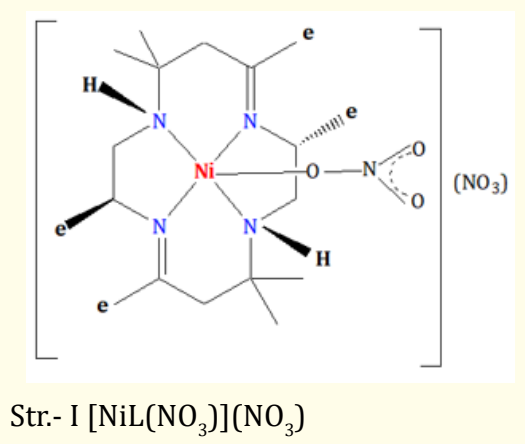

Figure a

$\left(\mathrm{NO}_{3}\right)$ complex.

\section{[NiL](SCN) ${ }_{2}$ and [NiL(NCS)](SCN)}

Reaction between $\mathrm{Ni}(\mathrm{NCS})_{2}$ (produced by the interaction of nickel(II) nitrate hexahydrate with potassium thiocyanate in methanol) and free ligand $\mathrm{L}$ afforded four coordinated square planar yellow complex, $[\mathrm{NiL}](\mathrm{SCN})_{2}$ and five coordinated square pyramidal light pink complex [NiL(NCS)](SCN) in methanol. The infrared spectra of $[\mathrm{NiL}](\mathrm{SCN})_{2}$ and $[\mathrm{NiL}(\mathrm{NCS})](\mathrm{SCN})$ display all characteristic bands due to $\mathrm{v}_{\mathrm{N}-\mathrm{H}^{\prime}}, \mathrm{v}_{\mathrm{C}-\mathrm{C}^{\prime}}, \mathrm{v}_{\mathrm{C}-\mathrm{H}}, \mathrm{v}_{\mathrm{Ni}-\mathrm{N}}$ and $\mathrm{v}_{\mathrm{CH} 3}$ stretching bands in the expected region. Further very strong band at $2035-2051 \mathrm{~cm}^{-1} \mathrm{im}-$ plies that NCS ${ }^{-}$is attached as ionic $\mathrm{SCN}^{-}$or coordinated with nickel by Ni-N bond $[33,34]$. The present complex [NiL(NCS)](SCN) displays a peak at $835 \mathrm{~cm}^{-1}$ which is due to $v_{\mathrm{CS}}$ band responsible for N-bonded NCS group [33]. Further the appearance of band at 482 $\mathrm{cm}^{-1}$ for this complex can be accounted for $\delta_{\mathrm{NCS}}$ for N-bonded isothiocyanato complex. However this band does not correspond to ligand in this region and are therefore assigned for fully N-bonded thiocyanate group [28,30,33,36-37]. Therefore the complex can be identified as $\mathrm{N}$-bonded isothiocyanato complex. The conductance values of [NiL] $(\mathrm{SCN})_{2}$ are 214 and $191 \mathrm{ohm}^{1} \mathrm{~cm}^{2} \mathrm{~mol}^{-1}$ in acetonitrile and water (Table-3) respectively which demonstrate that this complex is 1:2 electrolyte i.e. two thiocyanate ions are out of coordination sphere as expected. It is to be noted that this complex retain its color in these solvents. Again the molar conductivity value of $95 \mathrm{ohm}^{-1} \mathrm{~cm}^{2} \mathrm{~mol}^{-1}$ in DMSO solution of this complex corresponding to 1:1 electrolyte [29] can be assigned for equilibrium between square planar and octahedral geometry as shown in expression-3.

$[\mathrm{NiL}](\mathrm{SCN})_{2} \rightleftharpoons\left[\mathrm{NiL}(\mathrm{NCS})_{2}\right] \ldots \ldots \ldots$ (3)

The complex [NiL(NCS)](SCN) exhibits molar conductivity value $104 \mathrm{ohm}^{-1} \mathrm{~cm}^{2} \mathrm{~mol}^{-1}$ in DMSO (in this solvent it retained its color intact) corresponding to 1:1 electrolyte as expected for formula assigned. However the molar conductivity value of $241 \mathrm{ohm}^{-}$ ${ }^{1} \mathrm{~cm}^{2} \mathrm{~mol}^{-1}$ of the complex [NiL(NCS)](SCN) in water corresponding to $1: 2$ electrolyte can be accounted for expulsion of an anion i.e. NCS- from coordination sphere to form square planar complex $[\mathrm{NiL}](\mathrm{SCN})_{2}$ as expressed by the expression-4 or for the conversion of square pyramidal to octahedral diaqua complex as shown by expression-5.

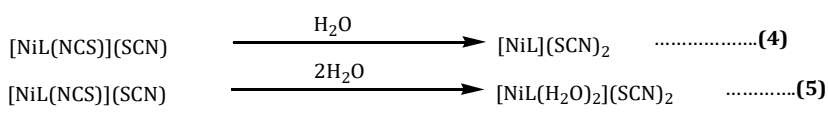

The magnetic moment value of $[\mathrm{NiL}](\mathrm{SCN})_{2}$ indicates it's diamagnetic character whereas the magnetic moment value (3.006 B.M) for the complex [NiL(NCS)](SCN) corresponds to two unpaired electrons as expected for paramagnetic square pyramidal complex. The electronic spectrum of square planar nickel(II) dithocyanate complex [NiL](SCN) $)_{2}$ displays d-d bands at $435 \mathrm{~nm}, 436$ $\mathrm{nm}$ and $445 \mathrm{~nm}$ in DMSO, water and acetonitrile respectively can be assigned to the ${ }^{1} \mathrm{~A}_{1 \mathrm{~g}} \rightarrow{ }^{1} \mathrm{~B}_{1 \mathrm{~g}}$ transition for square planar nickel(II) complexes. But the values 565-615 nm in DMSO supports the equilibrium between octahedral and square planar species. However in case of [NiL(NCS)](SCN), all characteristic bands in different solvents are observed expected for a high-spin $\mathrm{d}^{8}$ nickel(II) ion [31]. This study supports the square pyramidal geometry of the complex [NiL(NCS)](SCN) with $\mathrm{sp}^{3} \mathrm{~d}$ hybridization.

The ${ }^{1} \mathrm{H}-\mathrm{NMR}$ spectrum of $[\mathrm{NiL}](\mathrm{SCN})_{2}$ shows one overlapped 
singlet with a doublet at $0.884 \mathrm{ppm}$ and two singlets at $1.282 \mathrm{ppm}$ and $1.602 \mathrm{ppm}$ corresponding to $12 \mathrm{H}, 6 \mathrm{H}$ and $6 \mathrm{H}$ respectively. The overlapped signal can be accounted for a singlet corresponding to $6 \mathrm{H}$ for equatorial components of gem-dimethyl groups and a doublet arising out of six protons of methyl groups having equatorial orientation on chiral carbons. However the singlet at $1.282 \mathrm{ppm}$ can be assigned to the gem dimethyl groups having axial orientation. The other singlet at $1.602 \mathrm{ppm}$ corresponding to $6 \mathrm{H}$ can be accounted for protons of methyl groups on $\mathrm{sp}^{2}$ carbons at $\mathrm{C}_{5}$ and $\mathrm{C}_{12}$ positions. So an all equatorial arrangement of imine methyls and chiral methyls can be assigned for this complex. The other multiplets at $2.000 \mathrm{ppm}, 2.250 \mathrm{ppm}, 2.600 \mathrm{ppm}, 4.000 \mathrm{ppm}$ and 4.900 ppm can be attributed to the methine and methylene protons. However the signal at $7.220 \mathrm{ppm}$ can be attributed to NH protons. Since [NiL(NCS)](SCN) is a paramagnetic compound and ${ }^{1} \mathrm{H}-\mathrm{NMR}$ spectra of paramagnetic substances are less informative, so ${ }^{1} \mathrm{H}$ NMR spectrum of this complex has not been measured. Based on the discussed evidences, the following structures, II and III can be

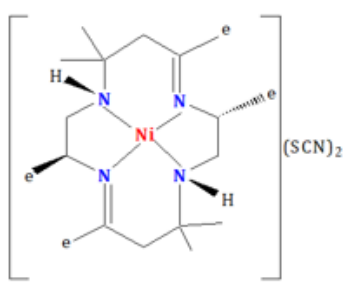

Str.-II $[\mathrm{NiL}](\mathrm{SCN})_{2}$

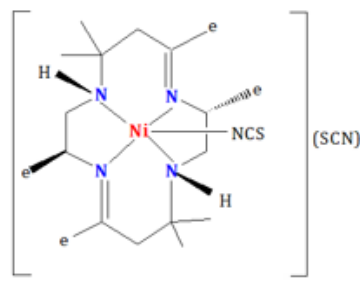

Str.-III [NiL(NCS)](SCN)
Figure b

assigned to $[\mathrm{NiL}](\mathrm{SCN})_{2}$ and $[\mathrm{NiL}(\mathrm{NCS})](\mathrm{SCN})$ respectively.

\section{$\left[\mathrm{NiL}\left(\mathrm{NO}_{2}\right)\right]\left(\mathrm{NO}_{3}\right)$}

Interaction between free ligand $\mathrm{L}$ and $\mathrm{Ni}\left(\mathrm{NO}_{2}\right)_{2}$ (produced by the reaction of nickel(II) nitrate hexahydrate with sodium nitrite) in methanol furnished a five coordinated square pyramidal light pink complex $\left[\mathrm{NiL}\left(\mathrm{NO}_{2}\right)\right]\left(\mathrm{NO}_{3}\right)$. Infrared spectrum of this complex shows $v_{\mathrm{N}-\mathrm{H}}, v_{\mathrm{C}-\mathrm{H}}, v_{\mathrm{C}-\mathrm{C}}$ and $v_{\mathrm{Ni}-\mathrm{N}}$ stretching bands at the expected regions. The band of $v_{\mathrm{CH} 3}$ is overlapped with the band of $\mathrm{NO}_{3}^{-}$group. Moreover the complex exhibits the $v_{\text {asym(NO2) }}$ band at $1459 \mathrm{~cm}^{-1}$, $v_{\text {sym(NO2) }}$ hump at $1320 \mathrm{~cm}^{-1}$ and stretching $\delta_{\mathrm{NO2}}$ band at $650 \mathrm{~cm}^{-1}$. Presence of $v_{\mathrm{Ni}-\mathrm{N}}$ band at $543 \mathrm{~cm}^{-1}$ and other bands in the proper region strongly support the complex to be $\mathrm{N}$-bonded nitro complex.
This complex exhibits molar conductivity value $96 \mathrm{ohm}^{-1} \mathrm{~cm}^{2} \mathrm{~mol}^{-1}$ in DMSO (in this solvent it retains its color intact) corresponding to 1:1 electrolyte [29] as expected for formula assigned. However the molar conductivity value of $231 \mathrm{ohm}^{-1} \mathrm{~cm}^{2} \mathrm{~mol}^{-1}$ of this complex in water corresponding to 1:2 electrolyte can be accounted for expulsion of an anion i.e. $\left(\mathrm{NO}_{2}^{-}\right)$from coordination sphere to form square planar complex [NiL] $\left(\mathrm{NO}_{2}\right)\left(\mathrm{NO}_{3}\right)$ (expression-7) or to form an octahedral diaqua complex, $\left[\mathrm{NiL}\left(\mathrm{H}_{2} \mathrm{O}\right)_{2}\right]\left(\mathrm{NO}_{2}\right)\left(\mathrm{NO}_{3}\right)$ as expressed by the expression-8.

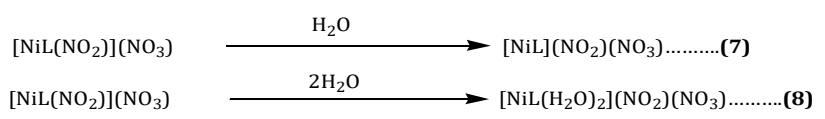

The magnetic moment value of $3.035 \mathrm{BM}$ of the complex is an indication that the complex $\left[\mathrm{NiL}\left(\mathrm{NO}_{2}\right)\right]\left(\mathrm{NO}_{3}\right)$ is paramagnetic corresponding to two unpaired electrons as expected for square pyramidal complex with $\mathrm{sp}^{3} \mathrm{~d}$ hybridization. The electronic spectrum of this complex in the visible region reveals all characteristic bands in different solvents as expected for a high-spin $\mathrm{d}^{8}$ nickel(II) ion [31]. This assignment also supports the square pyramidal geom-

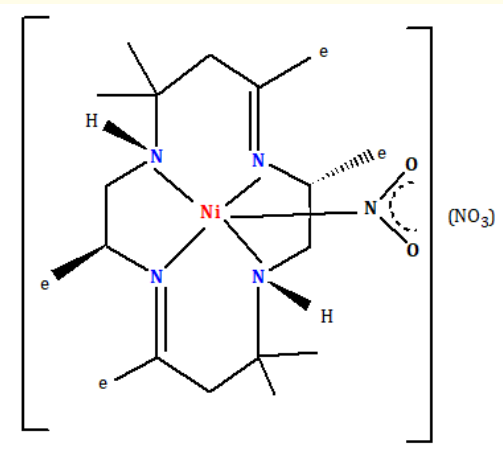

Str.-IV $\left[\mathrm{NiL}\left(\mathrm{NO}_{2}\right)\right]\left(\mathrm{NO}_{3}\right)$

Figure c

etry of this complex having $\mathrm{sp}^{3} \mathrm{~d}$ hybridization. Thus the following structure-IV can be assigned to $\left[\mathrm{NiL}\left(\mathrm{NO}_{2}\right)\right]\left(\mathrm{NO}_{3}\right)$ complex.

\section{[NiLX $\left.{ }_{\mathrm{m}}\right] \mathrm{X}_{\mathrm{n}}$ (Where $\mathrm{X}=\mathrm{Cl}, \mathrm{Br}$ or $\mathrm{I}, \mathrm{m}=\mathbf{0}$ or $\mathbf{1}$ and $\mathrm{n}=\mathbf{2}$ or $\mathbf{1}$ )}

These halonickel(II) complexes were synthesized by the same procedure followed for nickel(II) thiocyanate complexes by adding $\mathrm{KX}$ in the proper ratio. The infrared spectra of these complexes exhibit all characteristic bands due to $v_{\mathrm{N}-\mathrm{H}^{\prime}} \mathrm{v}_{\mathrm{C}-\mathrm{C}^{\prime}}, \mathrm{v}_{\mathrm{C}-\mathrm{H}}, \mathrm{v}_{\mathrm{Ni}-\mathrm{N}}$ and $\mathrm{v}_{\mathrm{CH} 3}$ 
stretching bands in the proper positions. The band for Ni-X could not be detected as the IR spectrum has not been carried out below $400 \mathrm{~cm}^{-1}$. All complexes showed expected molar conductivity values in DMSO (colour is retained as solid) corresponding to 1:1 electrolytes as expected for formula assigned. However the prospective values of these complexes in water corresponding to $1: 2$ electrolyte can be accounted for expulsion of an anion i.e. $\mathrm{Cl}^{-}, \mathrm{Br}^{-}$, $I^{-}$from coordination sphere to form square planar complex [NiL] $\mathrm{X}_{2}$ (expression-9) or octahedral diaqua complex, $\left[\mathrm{NiL}\left(\mathrm{H}_{2} \mathrm{O}\right)_{2}\right] \mathrm{X}_{2}$ as expressed by the expression-10 [21].

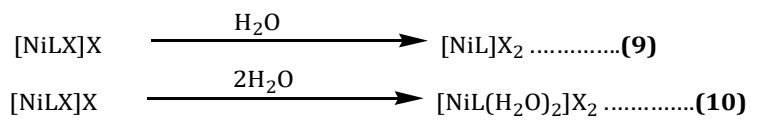

But the conductance value of [NiL]Br $\mathrm{Br}_{2}$ is $208 \mathrm{ohm}^{1} \mathrm{~cm}^{2} \mathrm{~mol}^{-1}$ in water indicates that this complex is 1:2 electrolyte i.e. two bromide ions are out of coordination sphere as expected. It is to be noted that this complex retains its colour in this solvent. Again the value of $75 \mathrm{ohm}^{-1} \mathrm{~cm}^{2} \mathrm{~mol}^{-1}$ in DMSO solution corresponding to 1:1 electrolyte can be assigned for equilibrium between square planar and octahedral geometry as shown in expression-11.

$[\mathrm{NiL}] \mathrm{Br}_{2} \rightleftharpoons\left[\mathrm{NiLBr}_{2}\right] \ldots \ldots \ldots \ldots . . . .(11)$

The magnetic moment values 3.073 BM, 3.09 BM and 3.023 BM of the complexes [NiLCl] Cl, [NiLBr]Br and [NiLI]I respectively demonstrate that these complexes are paramagnetic corresponding to two unpaired electrons as expected for square pyramidal complex with $\mathrm{sp}^{3} \mathrm{~d}$ hybridization. Whereas, the magnetochemical study of the complex [NiL]Br ${ }_{2}$ corresponds to diamagnetic compound as expected for square planar orientation with $\mathrm{dsp}^{2}$ hybridization. The electronic spectra of these paramagnetic complexes in the visible region reveal three absorption bands in the proper region in different solvents which are characteristic bands expected for a high-spin $d^{8}$ nickel(II) ion [31]. This study supports the square pyramidal geometry of these complexes having $\mathrm{sp}^{3} \mathrm{~d}$ hybridization. On the other hand the electronic spectrum of the complex, [NiL] $\mathrm{Br}_{2}$ displays d-d bands at $448 \mathrm{~nm}$ and $443 \mathrm{~nm}$ in DMSO and water respectively which can be assigned to the ${ }^{1} \mathrm{~A}_{1 \mathrm{~g}} \rightarrow{ }^{1} \mathrm{~B}_{1 \mathrm{~g}}$ transition for square planar nickel(II) complexes. Moreover the values 585-797 $\mathrm{nm}$ in DMSO indicates the equilibrium between octahedral and square planar species.

The ${ }^{1} \mathrm{H}$-NMR spectrum of this complex shows four sharp sin- glets at $1.26 \mathrm{ppm}, 1.36 \mathrm{ppm}, 1.90 \mathrm{ppm}$ and $2.09 \mathrm{ppm}$ corresponding to $6 \mathrm{H}, 6 \mathrm{H}, 4 \mathrm{H}$ and $6 \mathrm{H}$ respectively. The singlets at $1.26 \mathrm{ppm}$ and $1.36 \mathrm{ppm}$ can be assigned to the dimethyl groups having equatorial and axial orientation respectively. The $3^{\text {rd }}$ singlet at $1.90 \mathrm{ppm}$ corresponding to $4 \mathrm{H}$ can be accounted for $\mathrm{CH}_{2}$ protons at $\mathrm{C} 6$ and C13. The $4^{\text {th }}$ downfield singlet at $2.09 \mathrm{ppm}$ corresponding to $6 \mathrm{H}$ can be attributed to protons of methyl groups on $\mathrm{sp}^{2}$ carbons at $\mathrm{C} 3$ and C10 position. The upfield doublet appearing at $1.05 \mathrm{ppm}$ corresponding to $6 \mathrm{H}$ can be assigned to protons of methyl groups having equatorial orientation on chiral carbons. So an all equatorial arrangement of imine methyls and chiral methyls can be assigned for this complex, as like as other complexes of this study. The other multiplets $2.75 \mathrm{ppm}, 3.20 \mathrm{ppm}$ can be due to the methine, methy-

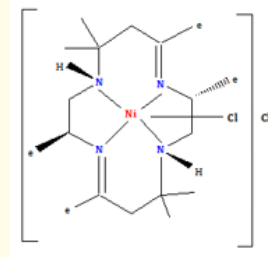

Str.-IV [NiLCl]Cl

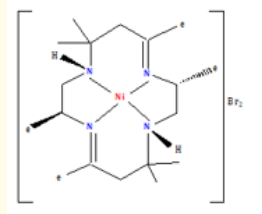

Str.-IV [NiL]Br2

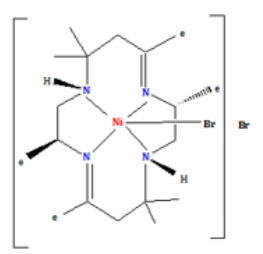

Str.-IV [NiLBr]Br

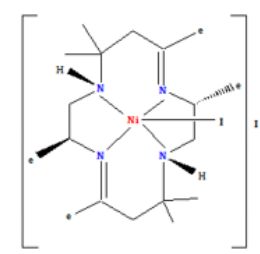

Str.-IV [NiLI]I

\section{Figure d}

lene and NH protons.Thus the following structures-V, VI, VII and VIII can be assigned for [NiLCl]Cl, [NiLBr]Br, [NiLI]I and [NiL] $\mathrm{Br}_{2}$ respectively.

\section{Antibacterial activities}

Studies on antimicrobial activity of macrocyclic ligands and their different metal complexes against different bacteria are available in the literature [36-43]. But the antibacterial activity of the nickel(II) complexes of concerned free ligand $L$ have not been studied so far. In this context antibacterial activity of concerned macrocyclic ligand and its nickel(II) complexes have been carried out against some important and selected gram positive and gram negative bacteria. As seen from the Table 1, the concerned free ligand did not show any activity but the concerned 
nickel(II) complexes show different amount of activity against different bacteria. However, all the complexes except nickel(II) dithiocyanate (C-02) showed remarkable activity against $B$. cereus but monochloridonickel(II) chloride (C-05) was the most potent among them. On the other hand, monoiodidonickel(II) iodide (C08) complex against $S$. aureus and E. coli, nickel(II) dithiocyanate (C-02), mononitronickel(II) nitrate (C-04), nickel(II) dibromide (C-06) and monobromidonickel(II) bromide (C-07) complex against E. coli, monobromidonickel(II) bromide (C-07) complex against $P$. aeruginosa showed good activity. However some complexes showed ineffectiveness against bacteria but a minute comparison on the result (Table 1) reveals that monoiodidonickel(II) iodide (C-08), monobromidonickel(II) bromide (C-07), nickel(II) dibromide (C-06) exhibited good activity against all bacteria. Similarly mononitronickel(II) nitrate (C-04) was active against all bacteria except $P$. aeruginosa, monochloridonickel(II) chloride (C-05), monoisothiocyanatonickel(II) thiocyanate (C-03) and mononitratonickel(II) nitrate (C-01) were also effective against all bacteria except E. coli. Antibacterial activity of solvent DMSO (as control) was also performed for the comparison which was inactive in all cases. Antibacterial activity of the metal complexes can

Table 1: Antibacterial data for the nickel(II) complexes.

\begin{tabular}{|c|c|c|c|c|c|}
\hline \multirow{3}{*}{$\begin{array}{c}\text { Sample } \\
\text { Code }\end{array}$} & \multirow{3}{*}{$\begin{array}{l}\text { Ligand and their } \\
\text { complexes }\end{array}$} & \multicolumn{4}{|c|}{$\begin{array}{c}\text { Zone of inhibition in } \\
\text { diameter }(\mathrm{mm})\end{array}$} \\
\hline & & \multicolumn{2}{|c|}{$\begin{array}{c}\text { Gram-negative } \\
\text { bacteria }\end{array}$} & \multicolumn{2}{|c|}{$\begin{array}{c}\text { Gram-positive } \\
\text { bacteria }\end{array}$} \\
\hline & & $\begin{array}{c}E . \\
\text { coli }\end{array}$ & $\begin{array}{c}P . \\
\text { aeruginosa }\end{array}$ & $\begin{array}{c}\text { S. } \\
\text { aureus }\end{array}$ & $\begin{array}{c}\text { B. } \\
\text { cereus }\end{array}$ \\
\hline $\mathrm{L}_{1}$ & $\mathrm{~L}$ & 0 & 0 & 0 & 0 \\
\hline C-01 & {$\left[\mathrm{NiL}\left(\mathrm{NO}_{3}\right)\right]\left(\mathrm{NO}_{3}\right)$} & 0 & 9 & 8 & 21 \\
\hline $\mathrm{C}-02$ & {$[\mathrm{NiL}](\mathrm{SCN})_{2}$} & 10 & 0 & 8 & 0 \\
\hline C-03 & {$[\mathrm{NiL}(\mathrm{NCS})](\mathrm{SCN})$} & 0 & 9 & 10 & 14 \\
\hline $\mathrm{C}-04$ & {$\left[\mathrm{NiL}\left(\mathrm{NO}_{2}\right)\right]\left(\mathrm{NO}_{3}\right)$} & 10 & 0 & 9 & 20 \\
\hline C-05 & {$[\mathrm{NiLClCl}$} & 0 & 9 & 11 & 23 \\
\hline C-06 & {$[\mathrm{NiL}] \mathrm{Br}_{2}$} & 11 & 8 & 9 & 16 \\
\hline $\mathrm{C}-07$ & {$[\mathrm{NiLBr}] \mathrm{Br}$} & 11 & 10 & 10 & 16 \\
\hline \multirow[t]{4}{*}{ C-08 } & {$[\mathrm{NiLI}] \mathrm{I}$} & 11 & 8 & 12 & 16 \\
\hline & Ampicillin(Standard) & 34 & 25 & 22 & 24 \\
\hline & $\mathrm{Ni}\left(\mathrm{NO}_{3}\right)_{2} \cdot 6 \mathrm{H}_{2} \mathrm{O}$ & 9 & 8 & 10 & 7 \\
\hline & DMSO(Control) & 0 & 0 & 0 & 0 \\
\hline
\end{tabular}

be explained by using the chelation theory [42]. To restricts further growth of organism, chelation helps to block the metal binding sites on enzymes of bacteria by enhancing the lipophilicity of central metal atom thereby block the synthesis of proteins [43].

\section{Conclusion}

This study reveals that interaction of macrocyclic ligand, L with nickel nitrate hexahydrate resulted in a five coordinated square pyramidal complex $\left[\mathrm{NiL}\left(\mathrm{NO}_{3}\right)\right]\left(\mathrm{NO}_{3}\right)$. Moreover a number of new five coordinated (high spin) square pyramidal complexes [NiL(NCS)] $(\mathrm{SCN}),\left[\mathrm{NiL}\left(\mathrm{NO}_{2}\right)\right]\left(\mathrm{NO}_{3}\right),[\mathrm{NiLCl}] \mathrm{Cl},[\mathrm{NiLBr}] \mathrm{Br}$ and [NiLI]I as well as four coordinated square planar $[\mathrm{NiL}](\mathrm{SCN})_{2}$ and $[\mathrm{NiL}] \mathrm{Br}_{2}$ were produced by the reaction of $\mathrm{L}$ with substituted nickel(II) salts. Antibacterial evaluation of the ligand and its nickel(II) complexes shows that, though the ligand was ineffective against the bacteria but most of the complexes complexes showed good antibacterial activities.

\section{Acknowledgement}

We sincerely acknowledge the Ministry of Education, People's Republic of Bangladesh, for sanctioning a research grant (PS2017552) to Professor Dr. Tapashi Ghosh Roy and Professor Dr. Debashis Palit, Department of Chemistry, University of Chittagong, Bangladesh.

\section{Bibliography}

1. El-Boraey HA and EL-Gammal OA. "Novel $\left(\mathrm{N}_{4}\right)$ Macrocyclic metal complexes: Synthesis, characterization, spectral studies and anticancer activity". Open Chemistry Journal 5 (2018): 5163.

2. Mallinson J and Ian C. "Macrocycles in new drug discovery". Future Medicinal Chemistry 4.11 (2012): 1409-1438.

3. Abo-Ghalia MH., et al. "Anticancer activities of newly synthesized chiral macrocyclic heptapeptide candidates". Molecules 25.1253 (2020): 1-13.

4. Sharma K., et al. "Synthesis, characterization and antifertility activity of new unsymmetrical macrocyclic complexes of tin(II)". Metal Based Drugs 7.5 (2000): 237-243.

5. Semenov VE., et al. "Antibacterial and antifungal activity of acyclic and macrocyclic uracil derivatives with quaternized nitrogen atoms in spacers". European Journal of Medicinal Chemistry 41.9 (2006): 1093-1101.

6. El-Boraey HA., et al. "Structural studies and anticancer activity of a novel $\left(\mathrm{N}_{6} \mathrm{O}_{4}\right)$ macrocyclic ligand and its $\mathrm{Cu}(\mathrm{II})$ complexes". Spectrochimica Acta Part A: Molecular and Biomolecular Spectroscopy 78.1 (2011): 360-370. 
7. Liang F., et al. "Copper complex of hydroxyl-Substituted triazamacrocyclic ligand and its antitumor activity". Bioorganic and Medicinal Chemistry Letters 13.15 (2003): 2469-2472.

8. Anandhan R., et al. "Synthesis and anti-inflammatory activity of triazole-based macrocyclic amides through click chemistry". Synthetic Communications 47.7 (2016): 671-679.

9. Pawar V., et al. "Synthesis, antioxidant and biocidal features of macrocyclic schiff bases with oxovanadium (V) complexes". Journal of Chemical and Pharmaceutical Research 3.1 (2011): 169-175.

10. Jhaumeer-Laulloo BS., et al. "Synthesis and anti-HIV activity of novel macrocyclic disulphide compounds with thioureylene group". Asian Journal of Chemistry 12.3 (2000): 775-780.

11. Ramadan AE-MM., et al "Macrocyclic nickel(II) complexes: Synthesis, characterization, superoxide scavenging activity and DNA-binding". Journal of Molecular Structure 1015 (2012): 56-66.

12. AL-Obaidi OHS., et al. "Synthesis, spectral and theoretical studies of macrocyclic $\mathrm{Cu}(\mathrm{II}), \mathrm{Ni}(\mathrm{II})$ and $\mathrm{Co}(\mathrm{II})$ complexes by template reaction of malonic acid with metal(II) chloride and urea or thiourea". American Chemical Science Journal 2.1 (2012): 1-11.

13. Fox S., et al. "Copper(II) and nickel(II) complexes of binucleating macrocyclic bis(disulfide)tetramine Ligands". Inorganic Chemistry 39.21 (2000): 4950-4961.

14. Hay RW., et al. "Nickel(II) complexes of the macrocyclic ligand 5-nitromethyl-5,7,12,14-tetramethyl-1,4,8,11-tetraazacyclotetradeca-4,11-diene containing a pendant nitro group". Transition Metal Chemistry 23 (1998): 165-167.

15. Osvath P., et al. "Copper(II) and nickel(II) complexes of pentaaza macrocyclic ligands". Australian Journal of Chemistry 40.2 (1987): 347-360.

16. Rafat F., et al. "Synthesis and characterization of $\mathrm{Ni}(\mathrm{II}), \mathrm{Cu}(\mathrm{II})$ and Co(III) complexes with polyamine-containing macrocycles bearing an aminoethyl pendant arm". Journal of the Serbian Chemical Society 69.8-9 (2004): 641-649.

17. Hinz FP and Margerum DW. "Ligand solvation and the macrocyclic effect. Nickel(II)-tetramine complexes". Inorganic Chemistry 13.12 (1974): 2941-2949.

18. Karn JL and Busch DH. "Nickel(II) complexes of the new macrocyclic ligands meso- and (+-)-2,12-dimethyl-3,7,11,17tetraazabicyclo [11.3.1] heptadeca-1(17),13,15-triene". Inorganic Chemistry 8.5 (1969): 1149-1153.
19. Gull $P$ and Hashmi AA. "Biological activity studies on metal complexes of macrocyclic schiff base ligand: Synthesis and spectroscopic characterization". Journal of the Brazilian Chemical Society 26.7 (2015): 1331-1337.

20. Biswas FB., et al. "Zinc(II) complexes of 3,10-C-meso-2,5,5,7,9,12,12,14- octamethyl-1,8-diaza-4,11-diazoniacyclotetradecane as its bis(acetate) trihydrate, $\left[\mathrm{L}_{\mathrm{B}} \mathrm{H}_{2}\right]$ $\left[\mathrm{CH}_{3} \mathrm{COO}\right]_{2} \cdot 3 \mathrm{H}_{2} \mathrm{O}$ : Synthesis, Characterization and antimicrobial studies". European Scientific Journal 14.24 (2018): 330-349.

21. Roy TG., et al. "Syntheses, characterization and anti-microbial activities of palladium(II) and palladium(IV) complexes of 3,10-C-meso- $\mathrm{Me}_{8}[14]$ diene $\left(\mathrm{L}^{1}\right)$ and its reduced isomeric anes $\left(\mathrm{L}_{\mathrm{A}}, \mathrm{L}_{\mathrm{B}}\right.$ and $\left.\mathrm{L}_{\mathrm{C}}\right)$. Crystal and molecular structure of $\left[\mathrm{PdL}^{1}\right]$ $\left[\mathrm{Pd}(\mathrm{SCN})_{4}\right]$ ". Applied Orgnometallic Chemistry 22 (2008): 637646.

22. Roy TG., et al. "Syntheses and antimicrobial activities of isomers of N(4), N(11)-dimethyl-3,10-C-meso- 3,5,7,7,10,12,14,14-octamethyl- 1,4,8,11- tetraazacyclotetradecane and their nickel(II) complexes". Inorganic Chemistry 46 (2007): 53725380.

23. Roy TG., et al. "Syntheses, electrolytic behaviour and antifungal activities of $\mathrm{Zn}(\mathrm{II})$ complexes of isomers of 3,10-C-meso3,5,7,7,10,12,14,14-octamethyl-1,4,8,11-tetraazacyclotetradecane (L). Crystal and molecular structure of $\left[\mathrm{ZnL}_{\mathrm{B}}\left(\mathrm{NO}_{3}\right)\right] \mathrm{NO}_{3}$ $\left(\mathrm{L}_{\mathrm{B}}=\right.$ a,e,a,e-L)". Inorganica Chimica Acta 371 (2011): 63-70.

24. Roy TG., et al. "Synthesis and antimicrobial activities of copper(II) complexes of $\mathrm{N}(4), \mathrm{N}(11)$-dimethyl $\left(\mathrm{L}_{\mathrm{BZ}}\right.$ and $\mathrm{L}_{\mathrm{CZ}}$ ) and $\mathrm{N}(4)$-monomethyl $\left(\mathrm{L}_{\mathrm{CZ1}}\right)-3,5,7,7,10,12,14,14$-octamethyl-1,4,8,11-tetraazacyclotetradecane. Crystal and molecular structure of $\left[\mathrm{CuL}_{\mathrm{CZ1}}\right]\left(\mathrm{ClO}_{4}\right)_{2}{ }_{2}$. Inorganica Chimica Acta 415 (2014): 124-131.

25. Alam S., et al. "Synthesis, characterization and antimicrobial studies of cadmium(II) complexes with a tetraazamacrocycle $\left(\mathrm{L}_{\mathrm{B}}\right)$ and its cyanoethyl $\mathrm{N}$-pendent derivative $\left(\mathrm{L}_{\mathrm{BX}}\right)$ ". Journal of Chemical Sciences 35 (2018): 1-11.

26. Roy TG., et al. "Synthesis, characterisation and antifungal activities of some new copper(II) complexes of octamethyl tetraazacyclotetradecadiene". Metal Based Drugs 6.6 (1999): 345-354.

27. Hazari SKS., et al. "Crystal structure of (3,10-C-meso$3,5,7,7,10,12,14,14$-octamethyl-1,4,8,11-tetraazacyclotetradeca-4,11- diene) copper dihydrate, $\left[\mathrm{Cu}\left(\left(\mathrm{Me}_{8}[14]\right.\right.\right.$ diene $\left.) \mathrm{ClO}_{4}\right)$ $\left.{ }_{2}\right] .2 \mathrm{H}_{2} \mathrm{O}^{\prime \prime}$. Zeitschrift für Kristallographie - New Crystal Structures 214 (1999): 51-52.

Citation: Tapashi Ghosh Roy., et al. "Synthesis, Characterization and Antibacterial Evaluation of Some New Nickel(II) Complexes of a Tetraazamacrocycle". Acta Scientific Pharmaceutical Sciences 5.1 (2020): 60-69. 
28. Bembi R., et al. "Polyazamacrocycles. 9. Characterization of diastereoisomeric trans- $\left(\mathrm{Co}\left(\mathrm{Me}_{8}[14] \mathrm{ane}\right) \mathrm{Cl}_{2}\right]^{+}$complexes". Inorganic Chemistry 30 (1991): 1403-1406.

29. Geary WJ., et al. "The use of conductivity measurements in organic solvents for the characterisation of coordination compounds". Coordination Chemistry Reviews 7.1 (1971): 81-122.

30. D’Aniello MJJ and Barefield EK. "A paramagnetic, square-pyramidal nickel(II) alkyl complex". Journal of the American Chemical Society 98.6 (1976): 1610-1611.

31. Lim IT., et al. "Synthesis and characterization of nickel(II) tetraaza macrocyclic complex with 1,1-cyclohexanediacetate ligand". Journal of the Korean Chemical Society 62.6 (2018): 427-432.

32. Roy TG., et al. "Synthesis and antimicrobial activities of some cadmium(II) and zinc(II) complexes of 3, 10- C- meso- 3, 5, 7, 7, 10, 12, 14, 14-octamethyl-1,4, 8,11-tetraazacyclotetradecadiene $\left(\mathrm{L}^{1}\right)^{\prime}$. Journal of the Bangladesh Chemical Society 22.2 (2009): 111-122.

33. Farago ME and James JM. "Coordination of thiocyanate and selenocyanate in some diamine complexes of nickel(II) and copper(II)". Inorganic Chemistry 4.12 (1965): 1706-1711.

34. Hassu RL and Burmeister JL. "Solvent control of the bonding mode of co-ordinated thiocyanate ion in cobalt(III) complexes". Chemical Communication 11(1971): 568-569.

35. Sabatini A and Bertini I. "Infrared spectra between 100 and $2500 \mathrm{~cm}^{-1}$ of some complex metal cyanates, thiocyanates and selenocyanates". Inorganic Chemistry 4.7 (1965): 959-961.

36. Roy TG., et al. "Axial addition in diastereoisomeric $\left[\mathrm{Cu}\left(\mathrm{Me}_{8}[14]\right.\right.$ ane $\left.)]\left(\mathrm{ClO}_{4}\right)_{2}\right]$ complexes: Anti-fungal and anti-bacterial activities". Journal of Coordination Chemistry 59.15 (2006): 17571767.

37. Roy TG., et al. "Copper(II) and nickel(II) complexes of N,Nbis(2-hydroxyethyl)-octamethyl-1,4,8,11-tetraaza-cyclotetradecane". European Journal of Inorganic Chemistry (2004): 4115 - 4123.

38. Roy TG., et al. "Synthesis, electrolytic behaviour and antimicrobial activities of cadmium complexes of isomers of 3,10-Cmeso-3,5,7,7,10,12,14,14-octamethyl-1,4,8,11-tetraazacyclotetradecane". Journal of Coordination Chemistry 40 (2007): 1567-1578.
39. Biswas FB., et al. "An in vitro antibacterial and antifungal effects of cadmium(II) complexes of hexamethyltetraazacyclotetradecadiene ligands". Asian Pacific Journal of Tropical Biomedicine 4.2 (2014): 618-623.

40. Barua S., et al. "Palladium complexes with hexamethyl tetraazacyclotetradecadiene (L) and isomers of its reduced form ('tet-a' and 'tet-b'): synthesis, characterization and antimicrobial studies". Journal of Inclusion Phenomena and Macrocyclic Chemistry 86 (2016): 291-303.

41. Yasmin S., et al. "Synthesis, characterization and antibacterial studies of zinc(II) complexes with hexamethyl-tetraazacyclotetradecadiene $\mathrm{Me}_{6}[14]$ diene and C-chiral isomers of its reduced analogue". Journal of Inclusion Phenomena and Macrocyclic Chemistry 87 (2017): 239-250.

42. Salehi M and Hasanzadeh M. "Characterization, crystal structures, electrochemical and antibacterial studies of four new binuclear cobalt(III) complexes derived from o-aminobenzyl alcohol". Inorganica Chimica Acta 426 (2015): 6-14.

43. Dharmaraj N., et al. "Ruthenium(II) complexes containing bidentate schiff bases and their antifungal activity". Transition Metal Chemistry 26 (2001): 105-109.

\section{Assets from publication with us}

- Prompt Acknowledgement after receiving the article

- Thorough Double blinded peer review

- Rapid Publication

- Issue of Publication Certificate

- High visibility of your Published work

Website: www.actascientific.com/

Submit Article: www.actascientific.com/submission.php

Email us: editor@actascientific.com

Contact us: +919182824667 